\title{
Phosphatidylinositol-Binding Clathrin Assembly Protein
}

National Cancer Institute

\section{Source}

National Cancer Institute. Phosphatidylinositol-Binding Clathrin Assembly Protein. NCI

Thesaurus. Code C84436.

Phosphatidylinositol-binding clathrin assembly protein (652 aa, 70 kDa) is encoded by the human PICALM gene. This protein plays a role in endosomal clathrin coat assembly. 